Check for updates

Cite this: RSC Adv., 2017, 7, 18144

Received 15th February 2017

Accepted 20th March 2017

DOI: 10.1039/c7ra01902e

rsc.li/rsc-advances

\title{
Indenothiophene-based asymmetric small molecules for organic solar cells $\uparrow$
}

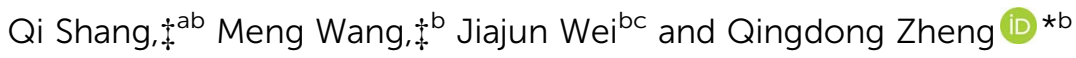

The development of organic semiconductors is of key importance in order to improve the performance of organic solar cells (OSCs). Three indenothiophene (IT)-containing small molecules (IT3T, ITFBT and IT2FBT) were designed and synthesized for small molecule OSCs. The thermal, optical, and electrochemical properties of the molecules were investigated. The optical bandgaps of the three small molecules are ranged from 1.80 to $2.20 \mathrm{eV}$ depending on different terminal groups flanked on the IT. We study the photovoltaic performances of the three molecules by fabricating OSCs with $\mathrm{PC}_{71} \mathrm{BM}$ as an electron acceptor. Among the three molecules, ITFBF exhibited the best power conversion efficiency of $4.57 \%$ with a high open circuit voltage $\left(V_{O C}\right)$ of $0.98 \mathrm{~V}$. We also briefly discuss structure-property guidelines for small molecules used for OSCs. The results demonstrate that IT-based small molecules are promising for small molecule OSCs with large $V_{\text {OCS. }}$

\section{Introduction}

Small molecule organic solar cells (OSCs), in which the photoactive layer commonly consists of a p-type semiconducting small molecule and a n-type fullerene derivative, have made significant progress in the past decade. ${ }^{\mathbf{1 - 4}}$ In comparison with polymers, semiconducting small molecules for OSCs have the advantages of well-defined structures, high purity, and superior batch-to-batch reproducibility. ${ }^{5-7}$ So far, the power conversion efficiency (PCE) of single-junction small molecule OSCs has exceeded $11 \%$. $^{3}$

For small molecule OSCs, the photoactive layer plays an important role not only in the open circuit voltage $\left(V_{\mathrm{OC}}\right)$, but also in the current density, both of which affect the PCE of the resulting device. Therefore, the innovations in active layer materials are attracting more and more attention. Although a large number of small molecule donors have been used for OSCs, the building blocks for efficient small molecule donors are limited to few symmetric units such as benzodithiophene, dithienosilole, indacenedithiophene, and diketopyrrolopyrrole. ${ }^{3,8-11}$ For example, dithienosilole-based (DTS) derivatives were used for small molecule OSCs as donor units,

${ }^{a}$ College of Chemistry, Fuzhou University, Fuzhou, 350108, P. R. China

${ }^{b}$ State Key Laboratory of Structural Chemistry, Fujian Institute of Research on the Structure of Matter, Chinese Academy of Sciences, Fuzhou, 350002, P. R. China. E-mail: qingdongzheng@fjirsm.ac.cn

'University of Chinese Academy of Sciences, 19 Yuquan Road, Beijing, 100049, P. R. China

$\dagger$ Electronic supplementary information (ESI) available: Thermogravimetric analysis results, stability of the OSC based on ITFBT: PC $_{71} \mathrm{BM}$, and the NMR spectra of the small molecules. See DOI: 10.1039/c7ra01902e

\$ These authors contributed equally to this work. leading to PCEs in the range from $5.8 \%$ to over $9 \% .{ }^{9}$ Wang et al. introduced indacenedithiophene-based (IDT) derivatives as donor units to produce a series of high performing small molecules for OSCs. ${ }^{10 d}$ Deng et al. reported benzodithiophenebased small molecules with PCEs over $11 \% .^{3}$ All the small molecules mentioned above have symmetric structures. At the same time, some examples of asymmetric small molecules were also reported for OSCs by Sharma et al. ${ }^{12}$ However, the number of asymmetric semiconducting molecules is much less than that of the symmetric counterparts due to less availability of asymmetric $\pi$-conjugated cores. ${ }^{4}$ Recently, our group first introduced asymmetric indenothiophene (IT) to construct donor-acceptor copolymers for polymer solar cells with PCEs over $9 \% .{ }^{13}$ However, the indenothiophene has never been used for constructing small molecule donors for OSCs.

In this context, three asymmetric indenothiophene-cored small molecules (IT3T, ITFBT and IT2FBT), were designed, synthesized, characterized, and used for the fabrication of OSCs. Three different terminal groups were flanked on the IT core for constructing the target small molecules in order to study the structure-property relationships of the IT-based small molecules. The chemical structures of the target small molecules are shown in Scheme 1. Among them, the devices based on ITFBT exhibited the best PCE of $4.57 \%$ and a $V_{\text {OC }}$ of $0.98 \mathrm{~V}$ under AM $1.5 \mathrm{G}$ irradiation $\left(100 \mathrm{~mW} \mathrm{~cm}^{-2}\right)$. IT3T and IT2FBT gave low PCEs of $0.71 \%$ and $1.92 \%$, respectively.

\section{Experimental section}

\subsection{Materials}

All reagents were purchased from commercial suppliers, and used as received without further purification unless otherwise 

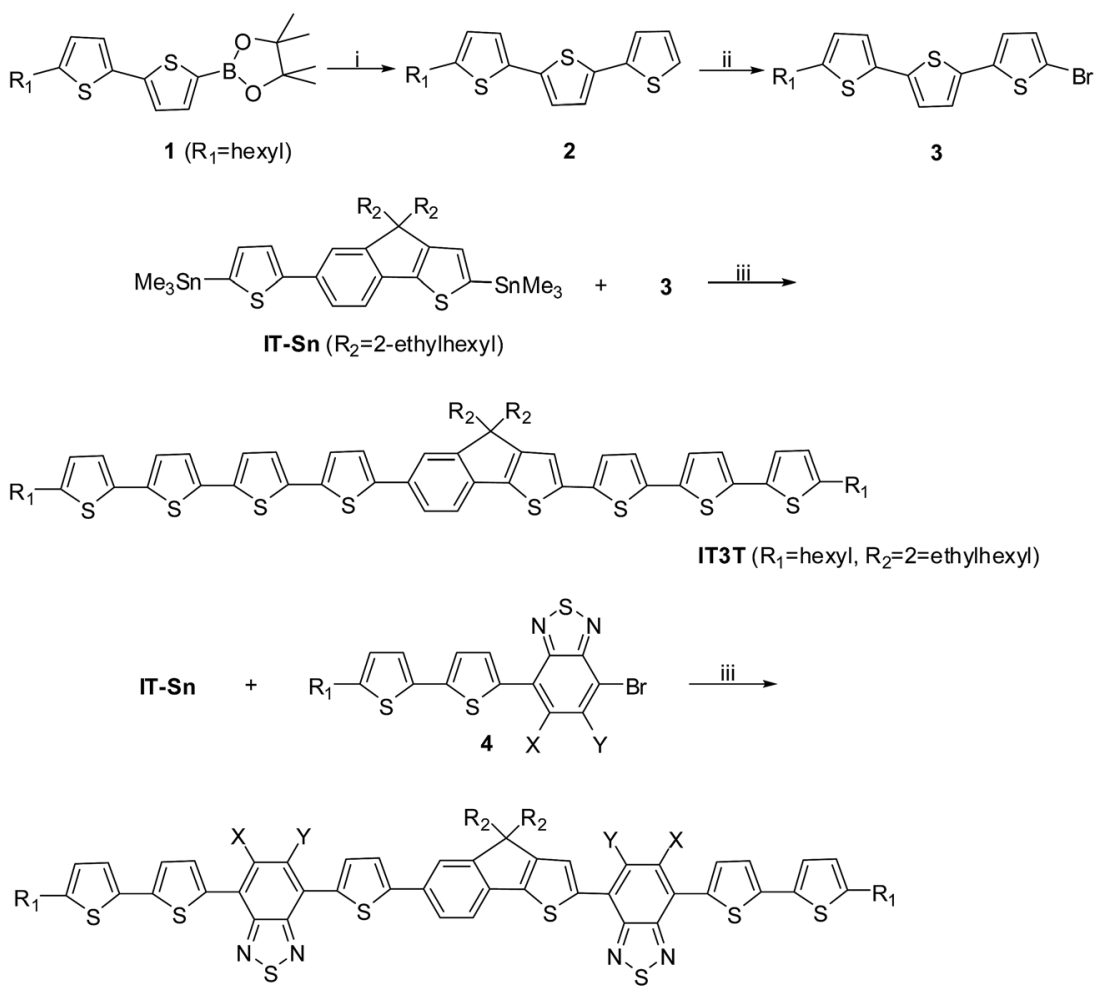

ITFBT $\left(X=H, Y=F, R_{1}=\right.$ hexyl, $R_{2}=2$-ethylhexyl)

IT2FBT $\left(X=Y=F, R_{1}=\right.$ hexyl, $R_{2}=2$-ethylhexyl)

Scheme 1 Synthesis of IT3T, ITFBT and IT2FBT: (i) 2-bromothiophene, $\mathrm{Pd}_{2}\left(\mathrm{dba}_{3}, \mathrm{P}(\mathrm{o}\right.$-tolyl) 3 , aqueous solution, aliquat 336 , toluene, reflux, $24 \mathrm{~h}$; (ii) $\mathrm{NBS}, \mathrm{CH}_{2} \mathrm{Cl}_{2}, 20^{\circ} \mathrm{C}$; (iii) $\mathrm{Pd}\left(\mathrm{PPh}_{3}\right)_{4}$, toluene, reflux, $24 \mathrm{~h}$.

stated. Column chromatography was conducted with silica gel (300-400 mesh).

\subsection{Synthesis of 5 -hexyl- $\left[2,2^{\prime} ; 5^{\prime}, 2^{\prime \prime}\right]$ terthiophene $(2)^{14}$}

2-(5'-Hexyl-[2,2'-bithiophen]-5-yl)-4,4,5,5-tetramethyl-1,3,2-dioxaborolane (1) (2.02 g, $5.4 \mathrm{mmol}), 2$-bromothiophene (4.34 g, $26.6 \mathrm{mmol}$ ), potassium phosphate tribasic $\left(2 \mathrm{M}\right.$ in $\mathrm{H}_{2} \mathrm{O}, 10.0$ $\mathrm{mmol}$ ) and 1 drop of aliquat 336 were added to $50 \mathrm{~mL}$ of toluene. After the mixture was degassed, tri(o-tolyl)phosphine $\left(\mathrm{P}(o \text {-tol })_{3}\right)(20 \mathrm{mg}, 0.066 \mathrm{mmol})$ and tris(dibenzylideneacetone) dipalladium $(0)\left(\operatorname{Pd}_{2}(\mathrm{dba})_{3}\right)(10 \mathrm{mg}, 0.011 \mathrm{mmol})$ were added. Then the reaction mixture was stirred vigorously at $110{ }^{\circ} \mathrm{C}$ for 24 h. After cooling to room temperature, the mixture was poured into methanol. The crude product was collected by filtration and purified by column chromatography using hexane as eluent to afford compound 2 as a yellow solid (1.06 g, 59\%). ${ }^{1} \mathrm{H} \mathrm{NMR}\left(\mathrm{CDCl}_{3}, 400 \mathrm{MHz}, \mathrm{ppm}\right): 7.22(\mathrm{~d}, J=4.8 \mathrm{~Hz}, 1 \mathrm{H}), 7.18$ $(\mathrm{d}, J=3.6 \mathrm{~Hz}, 1 \mathrm{H}), 7.08(\mathrm{~d}, J=3.6 \mathrm{~Hz}, 1 \mathrm{H}), 7.05-7.00(\mathrm{~m}, 3 \mathrm{H})$, $6.71(\mathrm{~d}, J=3.6 \mathrm{~Hz}, 1 \mathrm{H}), 2.82(\mathrm{t}, J=7.6 \mathrm{~Hz}, 2 \mathrm{H}), 1.70(\mathrm{~m}, 2 \mathrm{H})$, 1.44-1.32 (m, 6H), $0.92(\mathrm{t}, J=6.8 \mathrm{~Hz}, 3 \mathrm{H})$.

\subsection{Synthesis of $5^{\prime \prime}$-bromo-5-hexyl- $\left[2,2^{\prime} ; 5^{\prime}, 2^{\prime \prime}\right]$ terthiophene $(3)^{14}$}

$\mathrm{N}$-Bromosuccinimide (NBS) $(0.54 \mathrm{~g}, 3.0 \mathrm{mmol})$ was added slowly to a solution of compound $2(1.01 \mathrm{~g}, 3.0 \mathrm{mmol})$ in $30 \mathrm{~mL}$ of
$\mathrm{CH}_{2} \mathrm{Cl}_{2}$. After stirring the mixture at room temperature for $2 \mathrm{~h}$, $10 \mathrm{~mL}$ of water was added, and the mixture was then extracted with dichloromethane $(2 \times 50 \mathrm{~mL})$. The organic phase was washed with water twice, brine solution, then dried over anhydrous $\mathrm{MgSO}_{4}$. After removing the solvent, the crude product was purified by column chromatography to give a yellow solid (0.87 g, 70\%). ${ }^{1} \mathrm{H}$ NMR $\left(\mathrm{CDCl}_{3}, 400 \mathrm{MHz}, \mathrm{ppm}\right): 7.02-6.98$ $(\mathrm{m}, 4 \mathrm{H}), 6.92(\mathrm{~d}, J=3.6 \mathrm{~Hz}, 1 \mathrm{H}), 6.71(\mathrm{~d}, J=3.6 \mathrm{~Hz}, 1 \mathrm{H}), 2.81(\mathrm{t}$, $J=7.6 \mathrm{~Hz}, 2 \mathrm{H}), 1.70(\mathrm{~m}, 2 \mathrm{H}), 1.44-1.31(\mathrm{~m}, 6 \mathrm{H}), 0.92(\mathrm{t}, J=$ $6.8 \mathrm{~Hz}, 3 \mathrm{H})$.

\subsection{Synthesis of IT3T}

Compound 3 (0.50 g, $1.2 \mathrm{mmol})$, IT-Sn (0.33 g, $0.4 \mathrm{mmol})$ and 20 $\mathrm{mL}$ of dry toluene were added into a $50 \mathrm{~mL}$ two-neck flask. The solution was degassed by bubbling with nitrogen for $0.5 \mathrm{~h}$. $10 \mathrm{mg}$ of $\mathrm{Pd}\left(\mathrm{PPh}_{3}\right)_{4}$ was then added and the mixture was heated at $110{ }^{\circ} \mathrm{C}$ for $24 \mathrm{~h}$. After the solvent was removed, the crude product was purified by column chromatography to give a red solid $(0.31 \mathrm{~g}, 66 \%) .{ }^{1} \mathrm{H}$ NMR $\left(\mathrm{CDCl}_{3}, 400 \mathrm{MHz}, \mathrm{ppm}\right): 7.54$ (d, $J=$ $7.6 \mathrm{~Hz}, 2 \mathrm{H}), 7.37$ (d, $J=8.0 \mathrm{~Hz}, 1 \mathrm{H}), 7.27-7.25(\mathrm{~m}, 1 \mathrm{H}), 7.18$ (d, $J=3.6 \mathrm{~Hz}, 1 \mathrm{H}), 7.14-7.08(\mathrm{~m}, 7 \mathrm{H}), 7.04-7.01(\mathrm{~m}, 4 \mathrm{H}), 6.72(\mathrm{~d}, J=$ $3.6 \mathrm{~Hz}, 2 \mathrm{H}), 2.82(\mathrm{t}, J=7.6 \mathrm{~Hz}, 4 \mathrm{H}), 1.99(\mathrm{br}, 4 \mathrm{H}), 1.75-1.67(\mathrm{~m}$, $4 \mathrm{H}), 1.45-1.32(\mathrm{~m}, 12 \mathrm{H}), 1.06-0.85(\mathrm{~m}, 22 \mathrm{H}), 0.79-0.59(\mathrm{~m}, 14 \mathrm{H})$; ${ }^{13} \mathrm{C}$ NMR $\left(\mathrm{CDCl}_{3}, 100 \mathrm{MHz}, \mathrm{ppm}\right): 156.24,154.04,154.00$, 145.71, 144.12, 140.23, 139.24, 139.22, 139.19, 137.97, 137.10, $137.07,136.95,136.26,136.21,136.17,135.90,135.87,135.68$, 
135.30, 135.27, 135.23, 134.46, 130.54, 124.91, 124.76, 124.70, 124.67, 124.63, 124.32, 124.22, 124.15, 123.87, 123.64, 123.48, 123.30, 120.50, 119.03, 54.37, 43.54, 35.06, 34.26, 33.97, 31.65, 30.28, 28.87, 28.59, 27.50, 22.93, 22.67, 14.18, 14.12, 10.74 . HRMS (MALDI-DHB, $\mathrm{m} / z$ ): calcd for $\mathrm{C}_{67} \mathrm{H}_{78} \mathrm{~S}_{8}[\mathrm{M}]^{+}$1138.3869; found 1138.3864. Elemental analysis (\%) calc. for $\mathrm{C}_{67} \mathrm{H}_{78} \mathrm{~S}_{8}$ : C, 70.60; H, 6.90; found: C, 70.41; H, 6.91.

\subsection{Synthesis of ITFBT}

Following the same procedure as that used for IT3T, ITFBT was obtained as a dark red solid $(0.12 \mathrm{~g}, 44 \%)$ through a Stille coupling reaction between 7-bromo-5-fluoro-4-(5'-hexyl-[2,2'] bithiophenyl-5-yl)-benzo[1,2,5]thiadiazole (0.31 g, $0.6 \mathrm{mmol})$, and IT-Sn (0.17 g, $0.2 \mathrm{mmol}) .{ }^{1} \mathrm{H}$ NMR $\left(\mathrm{CDCl}_{3}, 400 \mathrm{MHz}, \mathrm{ppm}\right)$ : 8.19-8.12 (m, 4H), 7.78-7.67 (m, 3H), 7.64-7.55 (m, 1H), 7.48$7.41(\mathrm{~m}, 2 \mathrm{H}), 7.21-7.17(\mathrm{~m}, 2 \mathrm{H}), 7.13-7.10(\mathrm{~m}, 2 \mathrm{H}), 6.72-6.71$ $(\mathrm{m}, 2 \mathrm{H}), 2.81(\mathrm{t}, J=7.2 \mathrm{~Hz}, 4 \mathrm{H}), 2.16-2.03(\mathrm{~m}, 4 \mathrm{H}), 1.74-1.67(\mathrm{~m}$, $2 \mathrm{H}), 1.42-1.17(\mathrm{~m}, 14 \mathrm{H}), 1.14-0.78(\mathrm{~m}, 24 \mathrm{H}), 0.70-0.61(\mathrm{~m}, 12 \mathrm{H})$; ${ }^{13} \mathrm{C}$ NMR $\left(\mathrm{CDCl}_{3}, 100 \mathrm{MHz}, \mathrm{ppm}\right): 160.17,157.64,156.61$, 156.60, 154.60, 153.29, 149.67, 147.36, 147.33, 146.08, 143.84, 140.42 , 140.37, 140.29, 138.19, 136.91, 134.55, 131.14, 131.08, 131.03, 130.98, 130.86, 129.58, 129.54, 126.23, 126.12, 124.98, $124.94,123.88,123.70,123.23,123.06,120.93,120.91,119.71$, $119.50,116.17,115.86,115.68,110.85,110.82,110.66,54.53$, $43.70,35.14,34.10,34.08,31.60,30.26,28.82,28.40,27.53$, 22.86, 22.60, 14.15, 14.03, 10.68. HRMS (MALDI-DHB, $\mathrm{m} / \mathrm{z}$ ): calcd for $\mathrm{C}_{71} \mathrm{H}_{76} \mathrm{~F}_{2} \mathrm{~N}_{4} \mathrm{~S}_{8}[\mathrm{M}]^{+} 1278.3804$; found 1278.3798 . Elemental analysis (\%) calc. for $\mathrm{C}_{71} \mathrm{H}_{76} \mathrm{~F}_{2} \mathrm{~N}_{4} \mathrm{~S}_{8}$ : C, 66.63; H, 5.99; $\mathrm{N}, 4.38$; found: C, 66.70; H, 6.12; N, 4.13.

\subsection{Synthesis of IT2FBT}

Following the same procedure as that used for IT3T, IT2FBT was obtained a dark red solid $(0.14 \mathrm{~g}, 54 \%)$ through a Stille coupling reaction between 4-bromo-5,6-difluoro-7-(5'-hexyl$\left[2,2^{\prime}\right]$ bithiophenyl-5-yl)-benzo[1,2,5]thiadiazole $\quad(0.31 \mathrm{~g}, \quad 0.6$ $\mathrm{mmol})$ and IT-Sn (0.16 g, $0.2 \mathrm{mmol}) .{ }^{1} \mathrm{H} \mathrm{NMR}\left(\mathrm{CDCl}_{3}, 400 \mathrm{MHz}\right.$, ppm): 8.35-8.23 (m, 4H), 7.73-7.70 (m, 2H), 7.56-7.52 (m, 2H), 7.27-7.25 (m, 2H), 7.20-7.17 (m, 2H), 6.79-6.75 (m, 2H), $2.85(\mathrm{t}, J$ $=7.6 \mathrm{~Hz}, 4 \mathrm{H}), 2.20-2.06(\mathrm{~m}, 4 \mathrm{H}), 1.77-1.70(\mathrm{~m}, 2 \mathrm{H}), 1.46-1.23$ (m, 14H), 1.10-0.75 (m, 24H), 0.71-0.61 (m, 12H); ${ }^{13} \mathrm{C}$ NMR $\left(\mathrm{CDCl}_{3}, 100 \mathrm{MHz}, \mathrm{ppm}\right):$ 155.85, 155.83, 154.83, 150.91, 150.83, $148.75,148.73$, 148.66, 148.60, 148.24, 148.17, 146.45, 145.41, $141.36,141.28,141.20,138.24,138.20,134.26,132.11,132.09$, 132.02, 131.75, 131.71, 131.68, 131.66, 131.59, 131.16, 131.10, 129.97, 129.91, 129.87, 129.83, 126.13, 125.25, 125.05, 124.08, $124.04,123.14,120.85,119.77,111.21,54.51,43.64,35.16$, $34.26,34.15,31.65,30.30,28.88,28.40,27.50,22.92,22.66$, 14.17, 14.10, 10.75. HRMS (MALDI-DHB, $\mathrm{m} / \mathrm{z}$ ): calcd for $\mathrm{C}_{71} \mathrm{H}_{74} \mathrm{~F}_{4} \mathrm{~N}_{4} \mathrm{~S}_{8}[\mathrm{M}]^{+}$1314.3615; found 1314.3610. Elemental analysis (\%) calc. for $\mathrm{C}_{71} \mathrm{H}_{74} \mathrm{~F}_{4} \mathrm{~N}_{4} \mathrm{~S}_{8}$ : C, 64.80; H, 5.67; N, 4.26; found: C, 65.02; H, 5.71; N, 4.19.

\subsection{Instruments}

${ }^{1} \mathrm{H}$ and ${ }^{13} \mathrm{C}$ NMR spectra were recorded on a Bruker AVANCE400 spectrometer operating at 400 and $100 \mathrm{MHz}$, respectively. High-resolution mass spectroscopy (HRMS) measurements were performed on an IonSpec $4.7 \mathrm{~T}$ spectrometer. Absorption spectra were obtained by using a spectrophotometer (Lambda 365 UV/vis). The electrochemical cyclic voltammetry measurements were carried out on a $\mathrm{CHI} 700 \mathrm{E}$ electrochemical workstation. OSCs were measured by a Keithley 2440 source measurement unit under AM $1.5 \mathrm{G}$ irradiation $\left(100 \mathrm{~mW} \mathrm{~cm}^{-2}\right)$ on an Oriel sol3A simulator (Newport) which had been precisely calibrated with a NREL-certified silicon reference cell before testing. The external quantum efficiency (EQE) spectra were measured on a Newport EQE measuring system. Atomic force microscopy (AFM) was performed with the Bruker's Dimension FastScan at a tapping mode.

\subsection{Electrochemistry}

The cyclic voltammetry (CV) measurements were measured by using a three-electrode cell system (a Pt disk working electrode coated with thin films of small molecules, a Pt wire counter electrode and an $\mathrm{Ag} / \mathrm{AgNO}_{3}$ reference electrode). The measurements were performed in a $0.1 \mathrm{~mol} \mathrm{~L}^{-1}$ anhydrous and nitrogen-saturated tetrabutylammonium hexafluorophosphate $\left(\mathrm{Bu}_{4} \mathrm{NPF}_{6}\right)$ acetonitrile solution at a scan rate of $100 \mathrm{mV} \mathrm{s}^{-1}$. The energy level of the ferrocene was assumed to have an absolute energy level of $-4.82 \mathrm{eV}$ to vacuum. The highest occupied molecular orbital (HOMO) and the lowest unoccupied molecular orbital (LUMO) energy levels were calculated from the onset oxidation potentials $\left(E_{\text {ox }}\right)$ and onset reduction potentials $\left(E_{\text {red }}\right)$ vs. $\mathrm{Ag} / \mathrm{AgNO}_{3}$ reference electrode according to the following equations:

$$
\begin{aligned}
& E_{\mathrm{HOMO}}=-\left(E_{\mathrm{ox}}+4.82\right)(\mathrm{eV}) \\
& E_{\mathrm{LUMO}}=-\left(E_{\mathrm{red}}+4.82\right)(\mathrm{eV})
\end{aligned}
$$

\subsection{Fabrication of conventional OSCs}

The OSCs were fabricated with the device structure of: indium tin oxide (ITO)/poly(3,4-ethylenedioxythiophene):poly(styrenesulfonate) (PEDOT:PSS)/small-molecule:PC ${ }_{71} \mathrm{BM} / \mathrm{PDIN} / \mathrm{Al}$. ITO glass was cleaned by ultrasonication sequentially in detergent, water, acetone, and isopropanol for $30 \mathrm{~min}$ each and then dried in an oven at $80{ }^{\circ} \mathrm{C}$ overnight. After the ITO glass substrates were subjected to ultraviolet/ozone treatment for $15 \mathrm{~min}$, PEDOT:PSS (Baytron PVPAI 4083) which had been filtered through a $0.45 \mu \mathrm{m}$ filter was spin-coated on the ITO substrates at $3000 \mathrm{rpm}$ for $60 \mathrm{~s}$. Then the film-loaded substrates were dried at $140{ }^{\circ} \mathrm{C}$ in air for $15 \mathrm{~min}$. A mixture of smallmolecule : $\mathrm{PC}_{71} \mathrm{BM}(1: 2.2, \mathrm{w} / \mathrm{w})$ was dissolved in chlorobenzene at a concentration of $20 \mathrm{mg} \mathrm{mL}^{-1}$ and stirred overnight. Then the small-molecule : $\mathrm{PC}_{71} \mathrm{BM}$ solution was spin-cast at $1100 \mathrm{rpm}$ for $60 \mathrm{~s}$ to form the active layer. An electron injection interlayer was prepared by spin-coating a methanol solution of PDIN (1.5 mg mL $\mathrm{mL}^{-1}$ containing $0.2 \%$ acetic acid) to facilitate efficient electron injection. Finally, the negative electrode was prepared by thermally depositing $\sim 120 \mathrm{~nm}$ aluminum through a shadow mask under a high vacuum of $5 \times 10^{-5} \mathrm{~Pa}$. The device areas of the OSCs were fixed at $0.06 \mathrm{~cm}^{2}$. 


\section{Results and discussion}

\subsection{Synthesis and characterization}

The synthetic routes for the target molecules (IT3T, ITFBT and IT2FBT) are shown in Scheme 1 and the detailed synthetic procedures are shown in the Experimental section. The stannylized IT-Sn was prepared according to the procedures we reported previously. ${ }^{13 a}$ The synthesis of compound 3 started from compound 1, which was reacted with 2-bromothiophene to afford compound 2 in 59\% yield. Bromination of compound 2 afforded compound 3 in $70 \%$ yield. The Stille reaction between compound 3 and IT-Sn using $\mathrm{Pd}\left(\mathrm{PPh}_{3}\right)_{4}$ as a catalyst gave compound IT3T in 66\% yield. Similarly, ITFBT and IT2FBT were obtained by Stille coupling reactions between IT-Sn and the two benzothiadiazole-based bromides $\mathbf{4}$, respectively. The chemical structures and the purity of all new compounds were characterized by NMR, elemental analysis and high resolution mass spectrometry (HRMS).

\subsection{Thermal properties}

The thermal stability of the three small molecules was investigated by thermogravimetric analysis (TGA) at a heating rate of $10{ }^{\circ} \mathrm{C} \min ^{-1}$ under $\mathrm{N}_{2}$. IT3T, ITFBT and IT2FBT showed sufficiently high decomposition temperatures $\left(T_{\mathrm{d}}\right)$ of 403,405 , and $398^{\circ} \mathrm{C}$, respectively (Fig. $\mathrm{S} 1 \dagger$ and Table 1 ).

\subsection{Optical properties}

The absorption spectra of IT3T, ITFBT and IT2FBT in solution or in solid state are shown in Fig. 1, and the related parameters are summarized in Table 1 . Due to the identical acceptordonor-acceptor (A-D-A) structured backbone, ITFBT and IT2FBT exhibited analogous absorption bands both in the solution and in the thin film. For both ITFBT and IT2FBT, the shorter wavelength absorption bands originate from the $\pi-\pi^{*}$ transition and the longer ones are from the intramolecular charge transfer (ICT) between donor and acceptor units. However, IT3T exhibited only the $\pi-\pi^{*}$ transition band in solution or in thin film, which agrees with the donor-donor configuration of its molecule backbone. In going from the solution to the thin film, the absorption bands of all the three compounds become broadened and red-shifted. However, in comparison with IT3T, both IT2FBT and ITFBT exhibited a more red-shifted absorption in going from solution to thin film indicating a possible stronger $\pi-\pi$ interaction for latter
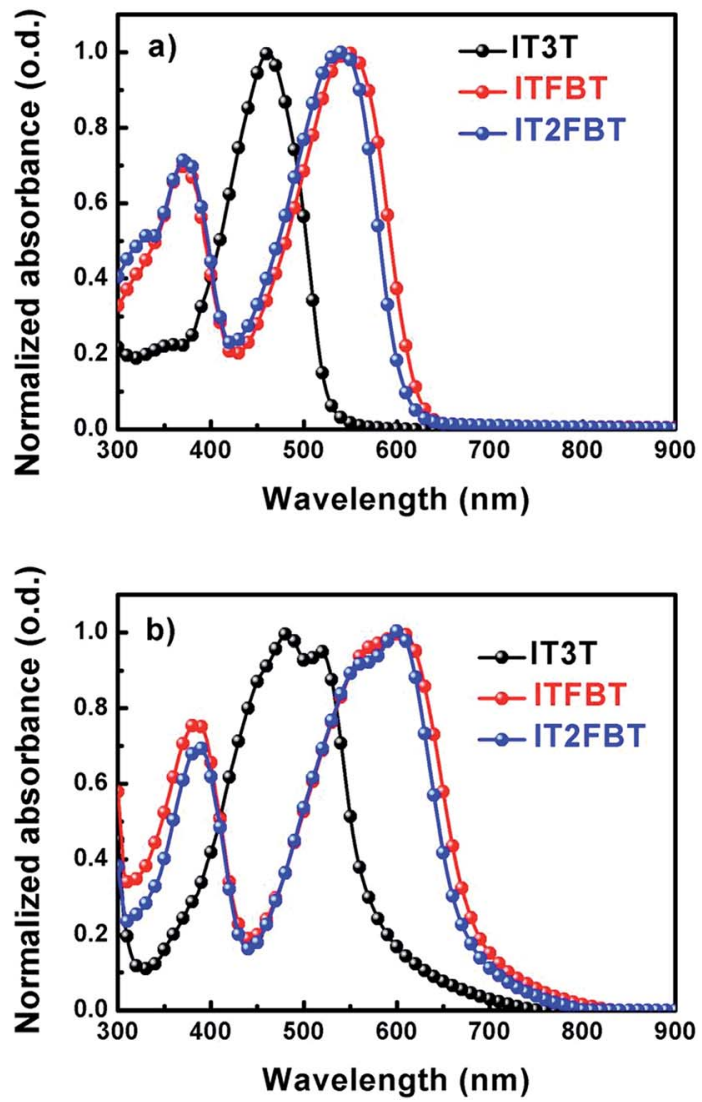

Fig. 1 Normalized absorption spectra of the small molecules in dichloromethane (a) and as-cast films (b).

two. The optical bandgaps of IT3T, ITFBT, and IT2FBT are 2.20, 1.81 and $1.84 \mathrm{eV}$, respectively. Among the three molecules, ITFBT possesses the smallest band gap of $1.81 \mathrm{eV}$, which is beneficial for enhanced light harvesting.

\subsection{Electrochemical properties}

To determine the HOMO and the LUMO energy levels of IT3T, ITFBT and IT2FBT, cyclic voltammetry (CV) measurement was performed and the results are shown in Fig. 2 and Table 1. The HOMO energy levels for IT3T, ITFBT and IT2FBT were estimated to be $-5.29,-5.35$ and $-5.46 \mathrm{eV}$, respectively. Both ITFBT and IT2FBT exhibit deeper HOMO energy levels in comparison with IT3T suggesting that the A-D-A structured backbone is favorable to down-shift the HOMO level of the resulting molecule.

Table 1 Summary of the intrinsic properties of IT3T, ITFBT and IT2FBT

\begin{tabular}{|c|c|c|c|c|c|c|c|}
\hline 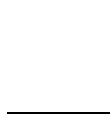 & \multicolumn{2}{|l|}{$\lambda_{\max }(\mathrm{nm})$} & $E_{\text {g,opt }}(\text { film })^{a}(\mathrm{eV})$ & $E_{\text {номо }}(\mathrm{eV})$ & $E_{\text {LUMO }}(\mathrm{eV})$ & $E_{\mathrm{g}, \mathrm{CV}}(\text { film })^{b}(\mathrm{eV})$ & $T_{\mathrm{d}}{ }^{c}\left({ }^{\circ} \mathrm{C}\right)$ \\
\hline ITFBT & 621 & 686 & 1.81 & -5.35 & -3.56 & 1.79 & 405 \\
\hline IT2FBT & 609 & 673 & 1.84 & -5.46 & -3.51 & 1.95 & 398 \\
\hline
\end{tabular}

${ }^{a}$ Estimated from the onset of the absorption spectra of thin films. ${ }^{b}$ Estimated from cyclic voltammetry. ${ }^{c}$ Decomposition temperature at $5 \%$ weight loss. 


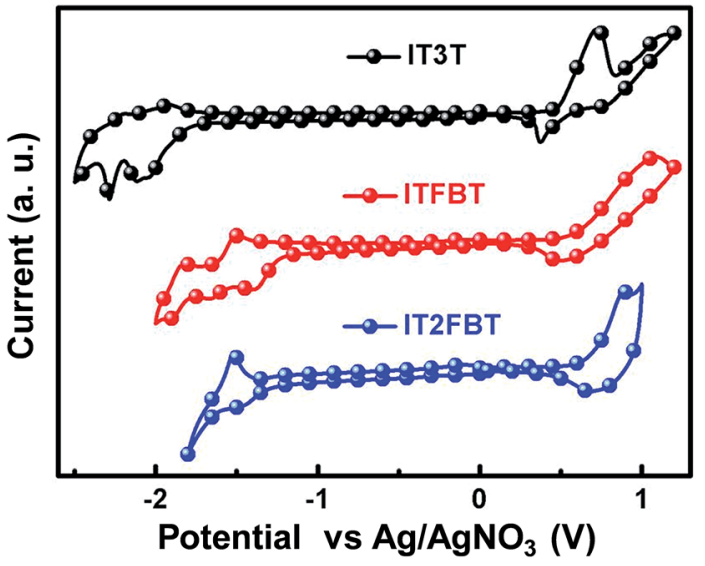

Fig. 2 Cyclic voltammogram of IT3T, ITFBT and IT2FBT thin films.

Compared to ITFBT, IT2FBT contains two additional electron withdrawing fluorine atoms thereby resulting in a deeper HOMO energy level of $-5.46 \mathrm{eV}$. The electrochemical bandgaps of the three small molecules are also estimated and they share the order of IT3T > IT2FBT > ITFBT, which agrees with their optical bandgap trend. The electrochemical properties of these molecules suggest that molecules with A-D-A structured backbone are beneficial for OSCs with enhanced light absorption as well as large $V_{\mathrm{OC}} \mathrm{S}$.

\subsection{Photovoltaic performance}

The photothose of the voltaic properties of IT3T, ITFBT and IT2FBT were investigated by fabricating OSCs with the device structure of indium tin oxide (ITO)/PEDOT:PSS/donor: $\mathrm{PC}_{71} \mathrm{BM} /$ PDIN/Al, where PDIN and PEDOT are 2,9-bis(3-(dimethylamino) propyl)anthra[2,1,9-def:6,5,10- $\left.d^{\prime} e^{\prime} f^{\prime}\right]$ diisoquinoline-1,3,8,10$(2 \mathrm{H}, 9 \mathrm{H})$-tetraone and poly(3,4-ethylenedioxythiophene)/ polystyrene sulfonate, respectively. The best performance OSCs were fabricated by using solutions with a donor (D)/ acceptor (A) ratio of $1: 2.2(\mathrm{w} / \mathrm{w})$, and the solutions were spincoated at a spinning rate of $1100 \mathrm{rpm}$. The device parameters of all three small molecule-based OSCs are summarized in Table 2. The current density-voltage $(J-V)$ curves of the OSCs are shown in Fig. 3a. It is showed that the OSC based on ITFBT: PC $_{71} \mathrm{BM}$ achieved the best performance among all the three small molecule-based devices. Without any additive, the device based on ITFBT:PC ${ }_{71} \mathrm{BM}$ exhibited a high $V_{\mathrm{OC}}$ of $0.98 \mathrm{~V}$, a $J_{\mathrm{SC}}$ of $10.24 \mathrm{~mA} \mathrm{~cm} \mathrm{c}^{-2}$ and a FF of 0.456 , all of which leads to a high PCE of $4.57 \%$. With the same A-D-A structured backbone and similar accepter units, IT2FBT-based OSC exhibited

Table 2 Device parameters of OSCs based on the small molecules

\begin{tabular}{llcll}
\hline Compounds & $V_{\mathrm{OC}}(\mathrm{V})$ & $J_{\mathrm{SC}}\left(\mathrm{mA} \mathrm{cm}^{-2}\right)$ & $\mathrm{FF}(\%)$ & $\mathrm{PCE}^{a}(\%)$ \\
\hline IT3T & 0.753 & 3.29 & 28.6 & $0.71(0.64)$ \\
ITFBT & 0.979 & 10.24 & 45.6 & $4.57(4.40)$ \\
IT2FBT & 1.01 & 6.25 & 30.5 & $1.92(1.82)$
\end{tabular}

${ }^{a}$ In parentheses are average values based on 8 devices.
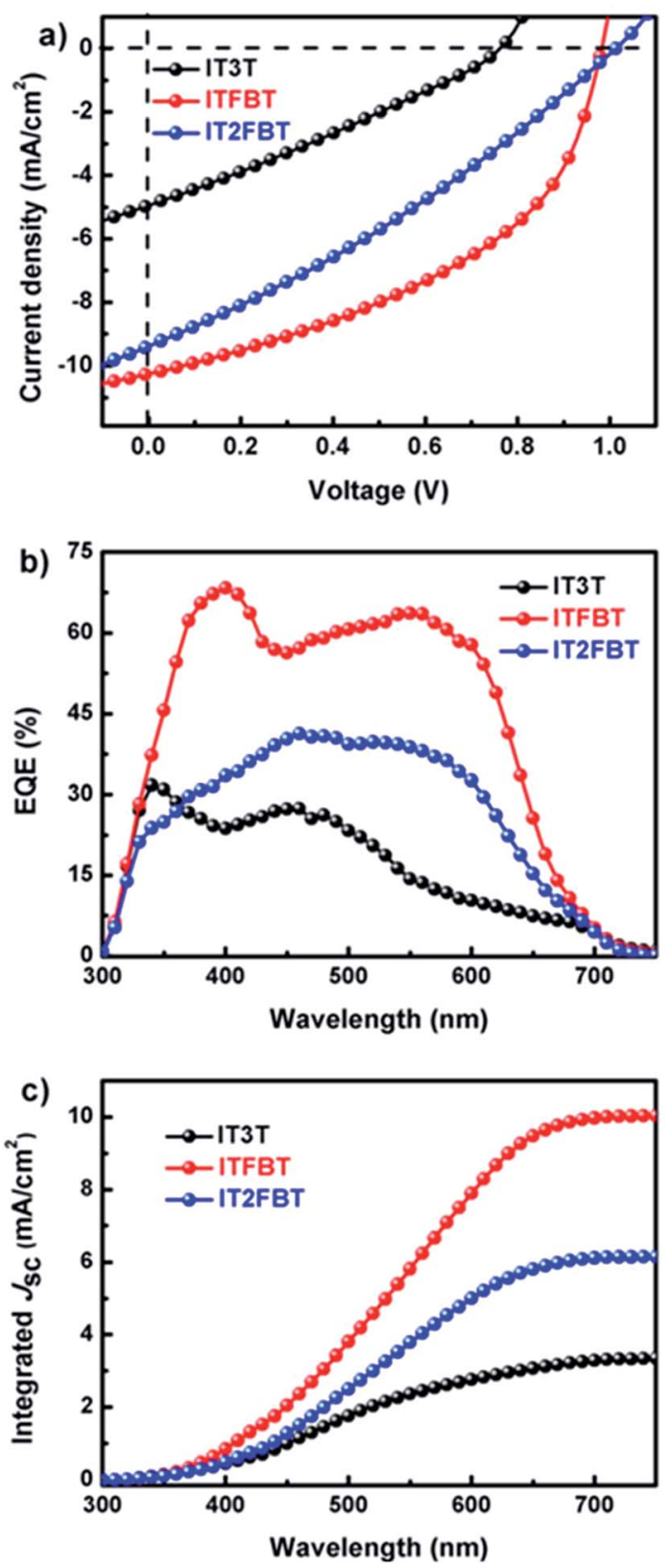

Fig. 3 (a) Current-voltage characteristic of organic solar cells under AM 1.5 G illumination (100 $\mathrm{mW} \mathrm{cm}^{-2}$ ); (b) EQE curves of OSCs; (c) corresponding integrated $J_{S C}$ curves of OSCs.

a lower PCE of $1.92 \%$ with a decreased $J_{\mathrm{SC}}$ of $6.25 \mathrm{~mA} \mathrm{~cm} \mathrm{~cm}^{-2}$, a reduced $\mathrm{FF}$ of $30.5 \%$, but a larger $V_{\mathrm{OC}}$ of $1.01 \mathrm{~V}$. The increased $V_{\text {OC }}$ is mainly attributed to the deeper HOMO energy level of IT2FBT as determined by cyclic voltammogram. However, the device based on IT3T:PC ${ }_{71} \mathrm{BM}$ showed a PCE of $0.71 \%$, with a low $J_{\mathrm{SC}}$ of $3.29 \mathrm{~mA} \mathrm{~cm} \mathrm{~cm}^{-2}$, a poor FF of $28.6 \%$, and a low $V_{\mathrm{OC}}$ of $0.753 \mathrm{~V}$. The inferior device performance for IT3T could be related to its relatively large bandgap, high HOMO energy level, as well as low carrier mobility. It should be noted that these conventional OSCs using PEDOT:PSS as anode buffer layer are relatively unstable over time in ambient conditions (Fig. S2 $\dagger$ ). However, the shelf stability of OSCs can be greatly enhanced by 
adopting an inverted device structure where the PEDOT:PSS is replaced by other inorganic buffer layers. ${ }^{15}$ To assure the accuracy of the PCE measurements, external quantum efficiencies (EQEs) of the OSCs were measured and shown in Fig. 3b. All the EQE curves cover a spectral response range from 300 to $700 \mathrm{~nm}$. In this range, the average EQE values of IT2FBT- and ITFBTbased devices are much higher than those of the IT3T-based device. The calculated $J_{\mathrm{SC}}$ value from EQE is $10.04 \mathrm{~mA} \mathrm{~cm}^{-2}$ for ITFBT, which is very close to that obtained from the $J-V$ measurement $\left(10.24 \mathrm{~mA} \mathrm{~cm} \mathrm{~cm}^{-2}\right)$ within $2 \%$ mismatch. The calculated $J_{\mathrm{SC}}$ values from the EQE curves of IT3T- and IT2FBTbased devices are also in agreement with the corresponding measured $J_{\mathrm{SC}}$ values. In order to know the origin of the observed photovoltaic performance differences among the three molecules, we measured the hole transport properties of the blend films by using the space charge limited current (SCLC) method. Hole-only devices with the device structure of ITO/PEDOT:PSS/ small molecules/ $\mathrm{MoO}_{3} / \mathrm{Au}$ were fabricated. As shown in Fig. 4, ITFBT shows the highest hole mobility of $4.8 \times 10^{-4} \mathrm{~cm}^{2} \mathrm{~V}^{-1}$ $\mathrm{s}^{-1}$ in comparison with IT3T $\left(7.9 \times 10^{-6} \mathrm{~cm}^{2} \mathrm{~V}^{-1} \mathrm{~s}^{-1}\right)$ and IT2FBT $\left(8.4 \times 10^{-5} \mathrm{~cm}^{2} \mathrm{~V}^{-1} \mathrm{~s}^{-1}\right)$. This highest hole mobility of the ITFBT-based device explains the higher $J_{\mathrm{SC}}$ and improved FF compared to the devices based on the other two molecules.

\subsection{Morphology}

The surface morphology of the small molecule: $\mathrm{PC}_{71} \mathrm{BM}$ blends was measured by tapping mode atomic force microscopy (AFM). The topography images and corresponding phase images of the small molecule blends are shown in Fig. 5. Among the three topographic images, the ITFBT: $\mathrm{PC}_{71} \mathrm{BM}$ film has the most smooth surface, with a small average root mean square (RMS) roughness value of $0.6 \mathrm{~nm}$. While the other two films based on IT3T:PC ${ }_{71} \mathrm{BM}$ and IT2FBT:PC ${ }_{71} \mathrm{BM}$, have larger RMS roughness values of 1.04 and $1.88 \mathrm{~nm}$, respectively, demonstrating the rougher surfaces than the ITFBT:PC ${ }_{71} \mathrm{BM}$ film. From the phase images, the ITFBT: $\mathrm{PC}_{71} \mathrm{BM}$ film shows clear phase seperation features with domain sizes of 10-20 nm. However, the phase seperation features are relatively unclear in the case of

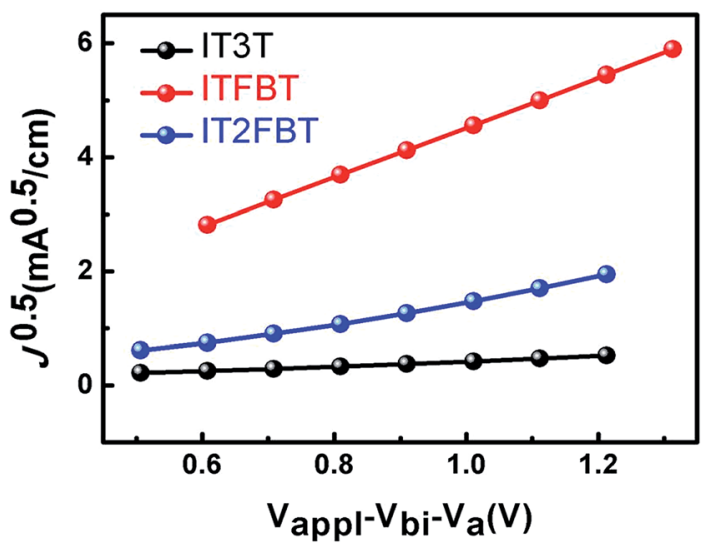

Fig. $4 J^{0.5}-V$ characteristics of hole-only devices based on IT3T:PC ${ }_{71} B M$ blends ( 119 nm thickness), ITFBT:PC ${ }_{71} B M(\sim 101 \mathrm{~nm}$ thickness), and IT2FBT:PC ${ }_{71} B M$ ( $~ 87 \mathrm{~nm}$ thickness).
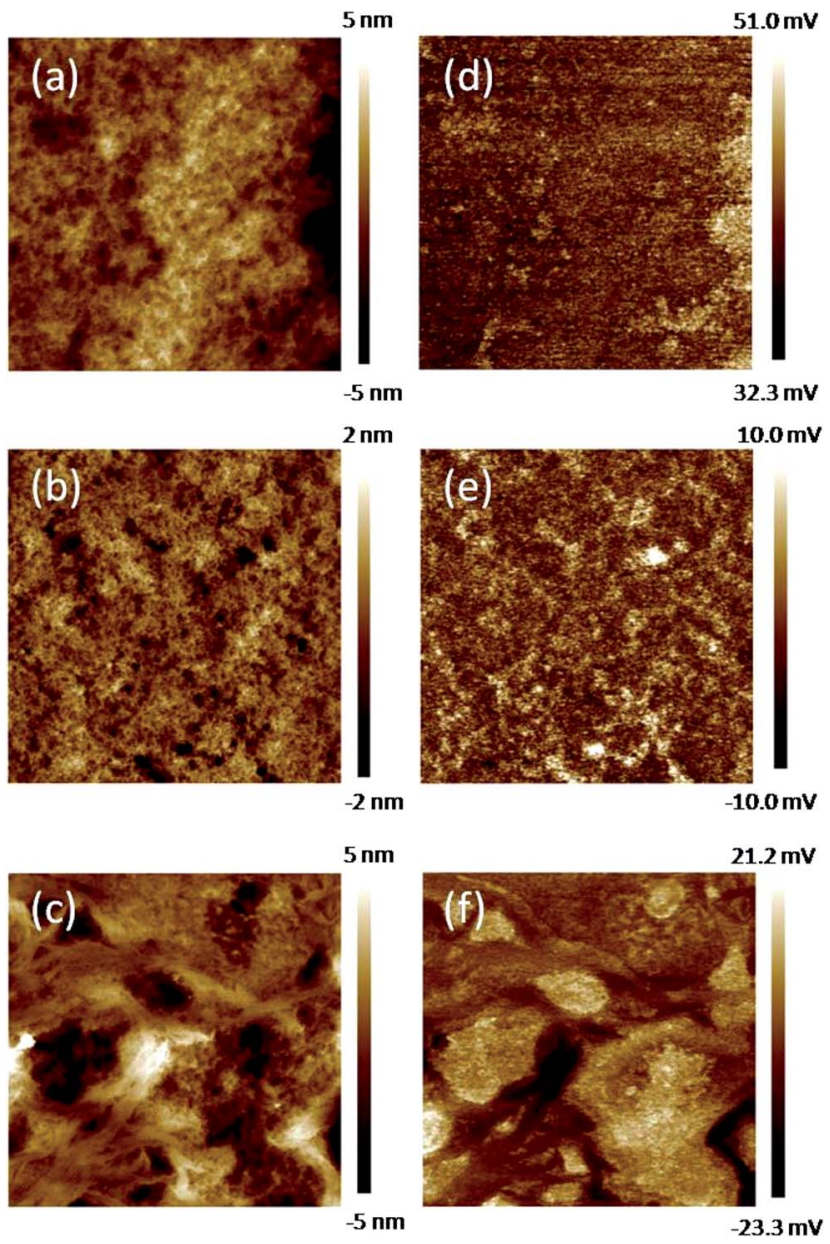

Fig. 5 Tapping mode AFM height $(a-c)$ and phase $(d-f)$ images of IT3T:PC ${ }_{71} B M$, ITFBT:PC ${ }_{71} B M$ and IT2FBT:PC ${ }_{71} B M$ films, respectively. All the images are $500 \times 500 \mathrm{~nm}$.

IT3T:PC ${ }_{71} \mathrm{BM}$ or IT2FBT:PC ${ }_{71} \mathrm{BM}$. At the same time, apparent aggregates with a domain size of more than $100 \mathrm{~nm}$ were found for the IT2FBT: $\mathrm{PC}_{71} \mathrm{BM}$ film. This scale is much larger than the exciton diffusion length $(<10 \mathrm{~nm})$, leading to an increased recombination rate of the photo-induced excitons before reaching the interfaces. It is believed that nanoscale phase separation enables a large interface area for exciton dissociation and a continuous percolating path for hole and electron transport to the corresponding electrodes. ${ }^{16}$ The morphology difference among the three small molecule blends explains the device performance difference for the three molecules with different ending groups.

\section{Conclusion}

In summary, we designed and synthesized three novel asymmetric small molecules (IT3T, ITFBT and IT2FBT) based on the indenothiophene core. Due to the electron-withdrawing ability of fluorinated benzothiadiazole units, ITFBT and IT2FBT exhibited deeper HOMO energy levels of -5.35 and $-5.46 \mathrm{eV}$ with smaller optical bandgaps $(1.81,1.84 \mathrm{eV})$, respectively, than those of IT3T $(-5.29 \mathrm{eV}, 2.20 \mathrm{eV})$, thus leading to the enhanced 
photovoltaic performance of ITFBT and IT2FBT. The best performance device based on ITFBT delivered a PCE of $4.57 \%$ with a $V_{\mathrm{OC}}$ of $0.98 \mathrm{~V}$, a $J_{\mathrm{SC}}$ of $10.24 \mathrm{~mA} \mathrm{~cm}^{-2}$ and a $\mathrm{FF}$ of 0.456 . IT2FBT and IT3T exhibited relatively lower PCEs of $1.92 \%$ and $0.71 \%$, respectively, which can be attributed to the unfavorable energy level, bandgap, carrier mobility or the morphology induced by the difference in their ending groups. The results suggest that the backbone configuration is an important factor determining the performance of the indenothiophene-based small molecules. Nonetheless, our results demonstrate that the asymmetric indenothiophene can be an excellent donor core for small molecule semiconductors.

\section{Acknowledgements}

This work was supported by the National Natural Science Foundation of China (No. U1605241, 61325026, 51561165011), the Strategic Priority Research Program of the Chinese Academy of Sciences (No. XDB20000000), and the CAS/SAFEA International Partnership Program for Creative Research Teams.

\section{Notes and references}

1 Y. Sun, G. C. Welch, W. L. Leong, C. J. Takacs, G. C. Bazan and A. J. Heeger, Nat. Mater., 2012, 11, 44-48.

2 H. Shang, H. Fan, Y. Liu, W. Hu, Y. Li and X. Zhan, Adv. Mater., 2011, 23, 1554-1557.

3 D. Deng, Y. Zhang, J. Zhang, Z. Wang, L. Zhu, J. Fang, B. Xia, Z. Wang, K. Lu, W. Ma and Z. Wei, Nat. Commun., 2016, 7, 13740.

4 Y. Lin, Y. Li and X. Zhan, Chem. Soc. Rev., 2012, 41, 42454272.

5 J. S. Wu, S. W. Cheng, Y. J. Cheng and C. S. Hsu, Chem. Soc. Rev., 2015, 44, 1113-1154.

6 B. Kan, M. Li, Q. Zhang, F. Liu, X. Wan, Y. Wang, W. Ni, G. Long, X. Yang, H. Feng, Y. Zuo, M. Zhang, F. Huang, Y. Cao, T. P. Russell and Y. Chen, J. Am. Chem. Soc., 2015, 137, 3886-3893.

7 J.-L. Wang, K.-K. Liu, J. Yan, Z. Wu, F. Liu, F. Xiao, Z.-F. Chang, H.-B. Wu, Y. Cao and T. P. Russell, J. Am. Chem. Soc., 2016, 138, 7687-7697.

8 (a) J. Zhou, X. Wan, Y. Liu, Y. Zuo, Z. Li, G. He, G. Long, W. Ni, C. X. Li, X. Su and Y. Chen, J. Am. Chem. Soc., 2012, 134, 16345-16351; (b) P. Dutta, J. Kim, S. H. Eom, W. H. Lee, I. N. Kang and S. H. Lee, ACS Appl. Mater. Interfaces, 2012, 4, 6669-6674; (c) Y. Chen, Z. Du, W. Chen, Q. Liu, L. Sun, M. Sun and R. Yang, Org. Electron., 2014, 15, 405-413; (d) Z. Wang, X. Xu, Z. Li, K. Feng, K. Li, Y. Li and Q. Peng, Adv. Electron. Mater., 2016, 2, 1600061.

9 (a) Y. Sun, J. Seifter, L. Huo, Y. Yang, B. B. Y. Hsu, H. Zhou, X. Sun, S. Xiao, L. Jiang and A. J. Heeger, Adv. Energy Mater.,
2015, 5, 1400987; (b) J. Zhou, X. Wan, Y. Liu, G. Long, F. Wang, Z. Li, Y. Zuo, C. Li and Y. Chen, Chem. Mater., 2011, 23, 4666-4668; (c) A. K. K. Kyaw, D. H. Wang, D. Wynands, J. Zhang, T.-Q. Nguyen, G. C. Bazan and A. J. Heeger, Nano Lett., 2013, 13, 3796-3801; (d) W. Li, W. Deng, K. Wu, G. Xie, C. Yang, H. Wu and Y. Cao, J. Mater. Chem. C, 2016, 4, 1972-1978; (e) V. Gupta, L. F. Lai, R. Datt, S. Chand, A. J. Heeger, G. C. Bazan and S. P. Singh, Chem. Commun., 2016, 52, 8596-8599; (f) C. D. Wessendorf, A. Perez-Rodriguez, J. Hanisch, A. P. Arndt, I. Ata, G. L. Schulz, A. Quintilla, P. Bäuerle, U. Lemmer, P. Wochner, E. Ahlswede and E. Barrena, J. Mater. Chem. A, 2016, 4, 2571-2580.

10 (a) W. Yong, M. Zhang, X. Xin, Z. Li, Y. Wu, X. Guo, Z. Yang and J. Hou, J. Mater. Chem. A, 2013, 1, 14214-14220; (b) X. Liu, Q. D. Li, Y. Li, X. Gong, S. J. Su and Y. Cao, J. Mater. Chem. A, 2014, 2, 4004-4013; (c) D. Liu, M. Xiao, Z. Du, Y. Yan, L. Han, V. A. L. Roy, M. Sun, W. Zhu, C. S. Lee and R. Yang, J. Mater. Chem. C, 2014, 2, 75237530; (d) J.-L. Wang, F. Xiao, J. Yan, Z. Wu, K.-K. Liu, Z.-F. Chang, R.-B. Zhang, H. Chen, H.-B. Wu and Y. Cao, Adv. Funct. Mater., 2016, 26, 1803-1812.

11 (a) B. Walker, A. B. Tomayo, X. D. Dang, P. Zalar, J. H. Seo, A. Garcia, M. Tantiwiwat and T. Q. Nguyen, Adv. Funct. Mater., 2009, 19, 3063-3069; (b) Y. Chen, A. Tang, X. Zhang, Z. Lu, J. Huang, C. Zhan and J. Yao, J. Mater. Chem. A, 2014, 2, 1869-1876; (c) Y. J. Kim, G. B. Lee, C. W. Jeon, Y. H. Kim, D. S. Chung and C. E. Park, $R S C$ Adv., 2015, 5, 3435-3442; (d) C. H. P. Kumar, K. Ganesh, T. Suresh, A. Sharma, K. Bhanuprakash, G. D. Sharma and M. Chandrasekharam, RSC Adv., 2015, 5, 93579-93590.

12 (a) T. Jadhav, R. Misra, S. Biswas and G. D. Sharma, Phys. Chem. Chem. Phys., 2015, 17, 26580-26588; (b) P. Gautam, R. Misra, S. A. Siddiqui and G. D. Sharma, Org. Electron., 2015, 19, 76-82; (c) P. Gautam, R. Misra, S. A. Siddiqui and G. D. Sharma, ACS Appl. Mater. Interfaces, 2015, 7, 1028310292; (d) Y. Patil, R. Misra, F. C. Chen, M. L. Keshtov and G. D. Sharma, RSC Adv., 2016, 6, 99685-99694.

13 (a) M. Wang, D. Cai, Z. Yin, S.-C. Chen, C.-F. Du and Q. Zheng, Adv. Mater., 2016, 28, 3359-3365; (b) M. Wang, Z. Wang, W. Ma, S.-C. Chen and Q. Zheng, Adv. Electron. Mater., 2016, 2, 1600340.

14 M. Melucci, G. Barbarella, M. Zambianchi, M. Benzi, F. Biscarini, M. Cavallini, A. Bongini, S. Fabbroni, M. Mazzeo, M. Anni and G. Gigli, Macromolecules, 2004, 37, 5692-5702.

15 Z. Yin, Q. Zheng, S.-C. Chen, D. Cai and Y. Ma, Adv. Energy Mater., 2016, 6, 1501493.

16 Q. Zheng, B. J. Jung, J. Sun and H. E. Katz, J. Am. Chem. Soc., 2010, 132, 5394-5404. 